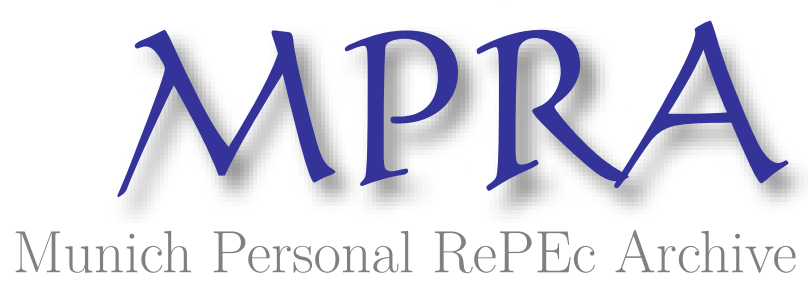

\title{
A More Precise Approach to Fiscal Consolidation and Sustainability
}

Afonso, Sérgio

23 January 2016

Online at https://mpra.ub.uni-muenchen.de/69072/

MPRA Paper No. 69072, posted 28 Jan 2016 10:39 UTC 


\title{
A More Precise Approach to Fiscal Consolidation and Sustainability
}

\author{
by Sérgio Pires Afonso \\ Independent
}

January 2016

\begin{abstract}
This paper argues that austerity is not a good solution for fiscal consolidation and sustainability. Therefore, it is imperative to find a new approach. This paper presents a mechanism to improve both tax compliance and fiscal sustainability.
\end{abstract}




\section{Introduction}

This paper argues that austerity does not work as intended. For instance, in the Eurozone countries undergoing austerity measures, the debt-to-GDP ratios keep rising and will create a larger problem in the future (Grauwe and Ji, 2013a). It is therefore of the utmost importance to find alternatives that do work for fiscal consolidation and sustainability. This paper presents one such alternative. In the next part of the paper, I will provide background information to explain why austerity fails. I will then introduce a new fiscal mechanism.

\section{Literature Review}

Austerity is self-defeating, particularly during a recession. Cutting government spending and raising taxes causes a drop in the GDP because households have less disposable income, which leads to lower tax revenue - consequently, the deficit fails to improve (Krugman, 2010). What can then happen is that growth can be less than forecasted (Blanchard and Leigh, 2013). Austerity leads to more unemployment, which causes more spending and makes controlling the deficit more difficult. It can even lead to the budget deficit increasing. Austerity does not work at all during a recession, particularly when interconnected countries apply it simultaneously (Holland and Portes, 2012; Wachtmeister and Ödeen, 2015). As a result of all the factors described above, the debt-to-GDP ratios have risen more in the Eurozone countries that have applied harsher austerity measures (Grauwe and Ji, 2013b). 
A highly relevant consequence of austerity is that it decreases tax compliance (Pappadà and Zylberberg, 2014; Carvalho and Pacheco, 2014; Schneider and Kearney, 2013). One of the reasons is that higher taxes lead people towards non-compliance, while another is that economic hardships force people to work in informal markets to make a living. This makes it even more challenging to achieve fiscal consolidation and sustainability.

Governments cannot sustain a large deficit indefinitely, but austerity measures do not work and the debt continues to grow; therefore, a new solution is necessary.

\section{A Better Approach}

In this framework, government wages and transfers would be linked to tax revenue, and the former would rise if the latter also rose, providing an incentive to increase tax compliance. However, not all of the new revenue would go to wages and transfers. The real goal of this framework is to have some of it go towards debt amortization. The amount for the wages would have to be sufficiently high to increase tax compliance, but low enough to provide more money for debt amortization,

Under the current fiscal framework, government employees and transfer recipients have the same income regardless of their tax compliance. By linking tax compliance, government wages and transfers closely, this type of budget would help to reduce tax evasion. Citizens could see very clearly that, if they do not pay taxes, their wages and transfers will be lower. One of the problems of austerity is that higher taxes mean a higher degree of tax evasion, making it more difficult to balance the budget. This type of mechanism addresses this factor. 
Wages and transfers would have a fixed component, which would be the same value as at present, and a variable component linked to an increase in tax revenue. This variable part would start at zero and could not become lower.

If tax revenue did indeed increase, the money would be stored in a bank account to be distributed as soon as possible to ensure that people received their rewards quickly in order to make compliance more attractive.

Tax increases would be measured by having a number of thresholds, whereafter the variable component of the wages and transfers would increase by a pre-set amount.

These measures would have the effect of reducing the size of the informal economy, which is $€ 2.15$ trillion in Europe (Schneider and Kearney, 2013), and would be highly relevant for fiscal sustainability. Motivating formal markets could create a virtuous cycle in which more people leave the grey economy and join the official one. One of the things that can result from this is social norms changing and making it less socially appealing to work in the informal market.

\section{Conclusion}

Connecting the value of government wages and social transfers to tax revenue would motivate tax compliance. The main goal of this strategy is to have a significant portion of the new tax revenue going to debt amortization, thereby contributing significantly to fiscal consolidation and sustainability. 
Having very high public debt-to-GDP ratios is dangerous for both debtors and creditors. By controlling their debt more precisely, policy makers who adopt this fiscal framework would contribute greatly not only to their country's well-being, but to that of the world's economy.

\section{References}

Blanchard, Olivier J., and Daniel Leigh. Growth forecast errors and fiscal multipliers. No. w18779. National Bureau of Economic Research (2013).

Carvalho, Daniela, and Luís Miguel Pacheco. "Tax compliance, corruption and deterrence: An application of the slippery model" (2014).

De Grauwe, Paul, and Yuemei Ji. "The legacy of austerity in the Eurozone" CEPS Commentary 4 (2013).

_. "Panic-driven austerity in the Eurozone and its implications" http://www. voxeu. org/article/panic-driven-austerity-eurozone-and-its-implications vol: e-pub (2013).

Holland, Dawn, and Jonathan Portes. "Self-defeating austerity?" National Institute Economic Review 222.1 (2012): F4.

Krugman, Paul. "Myths of austerity." The New York Times 1 (2010).

Pappadà, Francesco, and Yanos Zylberberg. "Austerity plans and tax evasion: theory and evidence from Greece." Unpublished Manuscript (2014). 
Schneider, Friedrich, and A. T. Kearney. "The Shadow Economy in Europe, 2013." Johannes Kepler Universitat, Linz (2013).

Wachtmeister, Eric, and Felix Ödeen. "Is Austerity an Effective Recovery Measure for the Eurozone?" (2015). 